\title{
LCA study of a plasma television device
}

\author{
Roland Hischier • Isabelle Baudin
}

Received: 15 May 2009/Accepted: 17 January 2010 /Published online: 1 April 2010

(C) Springer-Verlag 2010

\begin{abstract}
Purpose Nowadays, there is one television device for every four human beings, making television one of the most popular pieces of electrical and electronic equipment in our society, with the so-called flat-screen technologies gaining more and more market share. For one such technology, the plasma display panel (PDP), no complete life cycle assessment (LCA) studies have existed thus far, and therefore, the question as to their environmental performance, especially as compared with LCD technology, is still open. This paper describes a detailed LCA study of a PDP television, including a first comparison of it with the two competing technologies, the cathode ray tube and the liquid crystal display technologies.

Methods An LCA study from cradle to grave-i.e., from the extraction of the various resources used in the production to the final recycling or disposal activitieshas been established taking the complete life cycle of one PDP television as the functional unit.

Results Analysis of the complete life cycle of a PDP television shows that the distribution stage is of no importance. Of the remaining life cycle stages, the importance of the use phase depends on the actual production mix used for the electricity consumed. A fossil-based electricity
\end{abstract}

R. Hischier $(\bowtie)$

Life Cycle Assessment and Modelling Group,

Technology \& Society Lab (TSL), Swiss Federal Laboratories

for Material Testing and Research (Empa),

Lerchenfeldstrasse 5,

9014 St-Gallen, Switzerland

e-mail: Roland.Hischier@empa.ch

I. Baudin

Division Waste and Raw Materials,

Swiss Federal Office for the Environment (Bafu),

3003 Bern, Switzerland mix, such as the Union for the Coordination of Transmission of Electricity (UCTE)-mix, causes an impact in the use phase about two times higher than in the production phase. The production phase is dominated by the printed wiring boards and their various components - responsible for more than three quarters of the impact of this first life stage. Last but not least, in the end-of-life (EoL) phase, substantial environmental benefits are possible through a modern recycling system. A comparison of the PDP with competing technologies shows the PDP technology to be the more environmentally friendly one, based on the impact per square-inch of screen. All technologies show thereby a similar pictureproduction and use having high impacts, distribution being irrelevant, and EoL resulting in an ecological benefit.

Conclusions Hence, it is advisable to use electronic devices such as a PDP television as long as possible, because within the manufacturing stage, the production of the electronics is by far the most important production part. Some of this high environmental impact in electronics can be recovered in an up-to-date recycling system. The second most important life stage is the use phase, which depends on the production mix of the electricity consumed; the more non-renewable sources used for its production, the higher the impact of the use phase will appear. Hence, electronic devices should be used specifically and be turned off when not in use.

Keywords Cathode ray tube (CRT) television - Ecoinvent data $2.01 \cdot$ Life cycle assessment (LCA) - Liquid crystal device (LCD) television - Plasma television device . Screen technologies

\section{Background, aim and scope}

Institute for Prospective Technological Studies, Sevilla, SP (IPTS) (2003) states that "broadcast services are the most 
important mode of information delivery in the world today". The device used for the reception of this service-the television-is based on various inventions that were discovered in the time from about 1880 to the 1930s (Abramson 1987). Nowadays, there is one television device for every four human beings - with a penetration rate of about 300 million TV devices in Europe alone (IPTS 2003). That makes the television device one of the most popular pieces of electrical and electronic equipment in our society.

Whereas in recent decades, almost all devices were based on cathode ray tube (CRT) technology, the last couple of years have brought with them a more and more important transition from this voluminous technology to flat screen technologies. Currently, this market is dominated by two technologies: the plasma display panel (PDP) and the liquid crystal display (LCD). While the latter one is seen as the dominant technology for computer screens and so-called secondary television sets (e.g. the television set in the bedroom or bath room), the first one is considered the current choice for the principal TV device in a household. That is the case, although over the last 2 years or so, LCD technology_by making possible larger and larger devices - has been taking over increasingly larger parts of the market of the principal TV device as well.

The development of PDP technology started in the 1960s in the United States in the framework of improving the screen quality for students at university (Eden 2006). In this technology, an AC voltage is applied, generating a so-called plasma on the inner side of the PDP cell. This plasma then emits a visible light through the front side of the screen thanks to the phosphorous coating on the backside of the cell (Baudin 2006; Eden 2006). With its lifespan of about $60,000 \mathrm{~h}$ - but with a loss of $50 \%$ of the luminosity after the first $30,000 \mathrm{~h}$ (according to http:// www.plasmareview.fr/) - the technology is nowadays sufficiently reliable for use in a consumer product such as the television; for comparison, an LCD screen has a lifespan of about $45,000 \mathrm{~h}$, a CRT of only about 15,000 h (Socolof et al. 2005)

However, large LCD screens and different type of projection systems are competing more and more with PDP technology. The overall global market for television devices is estimated to be about 190 million devices sold in 2008 (IPTS 2003). Of them, only about $6 \%$ or 10 million devices are PDP devices - a market that is supposed to grow to about 25 million devices by 2011 (Matsushita 2006). In Europe, about 31 Mio television devices (about $2.5 \%$ of them PDP devices) were sold in 2004-a number estimated to rise to about 36.5 Mio (with a share for PDP of about 15\%) in 2010 (Stobbe 2007a). According to IPTS (2003), the leading screen manufacturers on the European market have indicated the phasing out of CRT displays for the European market by 2010 - due to inter alia the limitations of physical size as well as their low energy efficiency.

From an environmental point of view, according to a US study (Socolof et al. 2005) comparing CRT and LCD computer monitors using the instrument of life cycle assessment (LCA), CRT and LCD technologies each showed environmental advantages compared with the other depending on the impact category chosen. However, concerning the second flat screen technology (i.e. the PDP technology), no detailed environmental studies are known, apart from an "eco-efficiency" study reporting only on global warming and resource consumption data (Aoe 2003). But the question as to the PDP technology's overall environmental performance, especially as compared with LCD technology, has thus far remained open. Therefore, it has to be taken into account that television devices or information and communication technology (ICT) in general have a considerable impact on the environment. Directly, this impact is due to the fast growing number of devices produced - a production that causes a rather high environmental impact, as has been shown in a variety of studies in the last couple of years-e.g. for personal computers (von Geibler et al. 2003; Eugster et al. 2007; Huabo et al. 2009) or for mobile telecommunication devices (Scharnhorst 2005; Scharnhorst et al. 2006) indirectly, ICT applications can have a variety of impacts on the life cycle of other products and services - positive as well as negative impacts, ranging from, e.g. changes in the consumption pattern of our society to supporting tools for an integration of sustainability criteria in production chains (Hilty 2008; Hilty et al. 2008). Another important aspect is the recycling of electronic waste, as this type of waste and its treatment currently comprise a rapidly growing problem in many parts of the world (Widmer et al. 2005). As various studies in recent years have shown, a state-of-the-art recycling system allows one to recover a relevant amount of "secondary" materials, mainly metals, resulting in an environmental benefit for this last life cycle stage (Hischier et al. 2005; Eugster et al. 2007). Hence, researchers and politicians became very interested in this field (Hilty 2005; Widmer et al. 2005).

\section{Methodology}

\subsection{Goal and scope}

The goal of a diploma thesis written at Empa towards the end of 2006 was to establish a detailed LCA study of a plasma television device (Baudin 2006) due to a lack of respective studies at the time. Besides this detailed view on the environmental impacts of a plasma television device, a second goal of the same study was to do an initial 
comparison of the two competing technologies on the market (i.e. CRT and LCD). This paper presents a revised and updated version of those thesis results, established in the framework of activities concerning the extension of the life cycle inventory (LCI) database ecoinvent (ecoinvent Centre 2007).

The scope of the presented study is thus a traditional LCA from cradle to grave, i.e. from the extraction of the various resources used in the production of such a plasma television device to the final dismantling and recycling or disposal activities at the end of the life time of such a device. An overview of the system examined can be found in Fig. 1. The functional unit is defined as "The complete life cycle of a 42-inch $(=107 \mathrm{~cm})$ PDP television device; produced in Asia, used during 8 years, $4 \mathrm{~h} /$ day, in Europe and recycled in a European state-of-the-art recycling system". Table 1 summarises the key characteristics of the PDP device examined and at the same time shows the key characteristics for the two competing technologies used in the second part of this study for a comparison of these different television technologies, based on the same, comprehensive system boundaries.

\subsection{Life cycle inventory analysis}

\subsubsection{Plasma television device}

As in many other cases, the achievement of adequate LCI data in our study turned out to be very difficult, actually rather impossible. Due to a complete lack of respective information from the companies producing this type of television devices, a three-tiered "inverse approach", starting from a plasma television device at the end of its life, entering the Swiss WEEE systemthe so-called SWICO Recycling Guarantee [Swiss Economic Association for Information, Communications and Organizational Technology (SWICO)]—was chosen here. The various components of such a device and their respective weights were identified by dismantling this plasma television device in a first stage. Where necessary, a more detailed identification by chemical analysis methods was executed as well. In this way, a detailed composition of such a plasma television device was established - and its composition is summarised in Table 2. In a second stage, information from various international patents and from further literature (Snijkers and Klein, 2002; Inguchi et al. 2005; Lee 2006; Nishitani et al. 2006; Song and Choi, 2006) was taken, in order to further detail the composition of this plasma television device. This was especially necessary concerning the different layers inside the PDP cell.

Last but not least, in the third and last stage, the links from all the components and materials identified in this way-as well as the various production process stages leading up to the complete PDP device-to LCI data within a standard LCI database were established. In the origin diploma thesis (Baudin 2006), the database ecoinvent data v1.3 was used-a database that did not
Fig. 1 System boundaries for the complete life cycle of a plasma television device

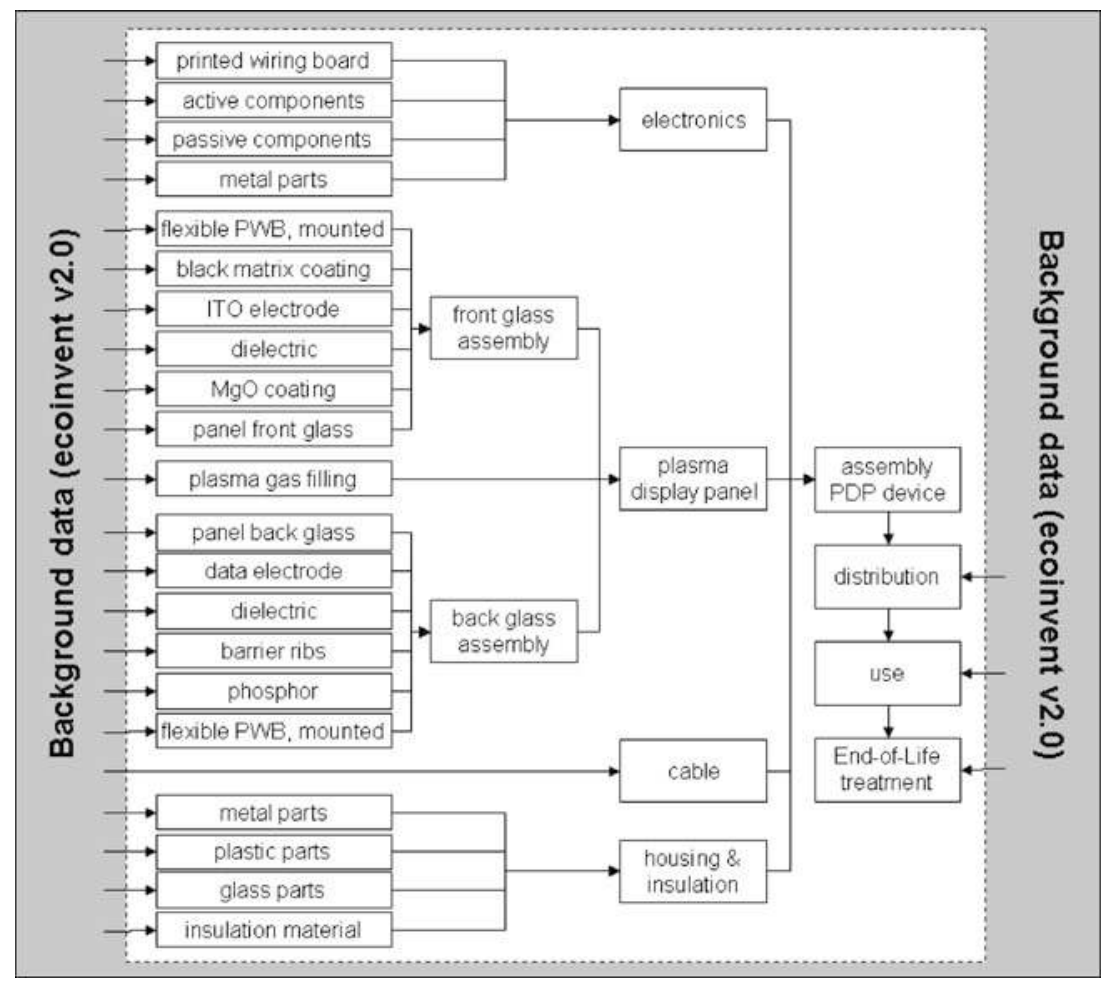


Table 1 Key characteristics of the study objects - a 42-inch colour plasma television device - and of competing devices based on CRT and LCD technology

\begin{tabular}{|c|c|c|c|c|}
\hline \multirow[t]{2}{*}{ Specification } & \multicolumn{2}{|l|}{ Plasma television (PDP) } & \multirow[t]{2}{*}{ CRT television } & \multirow[t]{2}{*}{ LCD television } \\
\hline & Range & Used values & & \\
\hline Screen size $\left[\mathrm{in}^{\mathrm{a}}\right] /$ format & 32 to 65 (to 102 )/16:9 & $42 / 16: 9$ & $32 / 16: 9$ & $32 / 16: 9$ \\
\hline Resolution (pixel $\times$ pixel) & $852 \times 480$ to $1,024 \times 1,024$ & $1,024 \times 768$ & na & $1,366 \times 768$ \\
\hline Luminosity [cd/m2] & 430 to 1,400 & 1,400 & na & 500 \\
\hline Contrast & $1,000: 1$ to $10,000: 1$ & $3,000: 1$ & na & $15,000: 1$ \\
\hline Weight $[\mathrm{kg}]$ & 29 to 36 & 30.2 & 48.3 & 16.0 \\
\hline \multicolumn{5}{|l|}{ Electricity consumption [W] } \\
\hline On & 220 to 420 & 303 & 115 & 138 \\
\hline Stand-by & 0.5 to 3.6 & 1.6 & 1.8 & 1.7 \\
\hline
\end{tabular}

${ }^{\mathrm{a}} 1 \mathrm{in}=2.54 \mathrm{~cm}$

na not applicable

contain specific data for electronic components. In the framework of the extension of the database ecoinvent with data for the electronics sector, the calculations of this plasma television device were revised and adapted to the new possibilities of this most up-to-date and comprehensive international LCI database. In this way, the various printed wiring boards (PWB) mentioned in Table 2 were modelled with the unspecific, generic PWB datasets from ecoinvent. Apart from the PWB, further improvements were possible - especially for the different layers inside the PDP cell. Table 3 summarises the key characteristics and assumptions used in this LCA study here for the various components, materials and processing steps of the here examined PDP device.

For the use pattern, the original information used in Baudin (2006) was replaced by information about the European use pattern reported in the EuP preparatory study "televisions" (Stobbe 2007b). Hence, an average watching time of $4 \mathrm{~h}$ /day was used, assuming off-mode for the remaining time 4 weeks (during holidays) and the (passive) stand-by mode for the remaining time. No distinction was made here between passive and active stand-by; the latter one characterised by an energy consumption ten to 20 times higher and used for updating, e.g. electronic programme systems (programme guide). For the electricity consumption in the use phase, various studies in the last couple of years (e.g. DCE 2007; Stobbe 2007c) have shown that there is a large spread between energy efficient and less efficient devices of the same size within a given technology. Comparing the ranges for 42-inch PDP devices shows values on the order of less than $225 \mathrm{~W}$ to almost $350 \mathrm{~W}$. For this study, the value of $303 \mathrm{~W}$, reported in Baudin (2006), was used.

For the total lifespan, the number of 8 years was used (value for first use according to Stobbe (2007b)), followed by a subsequent treatment in a state-of-the-art WEEE recycling system such as, e.g. that established in Switzerland (and described, e.g. in Hischier et al. (2005)). Credits are given in this study for all amounts of recycled material (i.e. metals) as well as the amount of recovered energy from the incineration processes. More details concerning the EoL processes for the various materials, as well as the benefits from these recycling activities can be found in Table 3 (section 3.2.3).

An extract - showing some of the most important emission factors to water, air as well as resource fractions - of the resulting, cumulative life cycle inventory data for the complete life cycle of a PDP device is shown in Table 4.
Table 2 Main components of the dismantled plasma television device

\begin{tabular}{lrrl}
\hline Component & \multicolumn{2}{l}{ Weight } & Main materials \\
\cline { 2 - 3 } & {$[\mathrm{kg}]$} & {$[\%]$} & \\
\hline Housing & 15.73 & 48.3 & Metals, plastics, glass \\
Internal protection material & 0.07 & 0.2 & Silicon, plastics \\
Plasma panel & 8.46 & 26.0 & Glass with various coatings \\
Electronics & 5.62 & 17.3 & Printed wiring boards \\
Cables & 0.27 & 0.8 & Copper, plastics \\
Packaging & 2.40 & 7.4 & Carton board, EPS \\
Total & 32.54 & 100 & \\
\hline
\end{tabular}


Table 3 Values and assumptions for the various process steps in the life cycle of a plasma television device

\begin{tabular}{|c|c|}
\hline Process step & Value and remarks \\
\hline \multirow[t]{7}{*}{ Production } & Housing: composition data from Baudin (2006), linked to respective datasets from ecoinvent v2.01 \\
\hline & Insulation protection material: composition data from Baudin (2006), linked to respective datasets from ecoinvent v2.01 \\
\hline & Plasma panel: composition data from Baudin (2006), linked to respective datasets from ecoinvent v2.01 \\
\hline & $\begin{array}{l}\text { Electronics: amount and type of printed wiring board according to Baudin (2006); represented then by the unspecified } \\
\text { surface-mounted or through-hole printed wiring board datasets from ecoinvent v2.01 }\end{array}$ \\
\hline & Cables: amount and type of cable according to Baudin (2006) linked to respective data from ecoinvent v2.01 \\
\hline & Packaging: composition data from Baudin (2006) linked to the respective data from ecoinvent v2.01 \\
\hline & $\begin{array}{l}\text { Assembly: rough estimation of auxillaries (chemicals, gases) and energy amount based on Matsushita (2006). Included is in } \\
\text { addition to the transport of all electronic components and the fabricated plasma panel from Asia (Korea, Japan) to the final } \\
\text { assembly site in Europe (Turkey) by ocean ship, as stipulated in Baudin (2006) }\end{array}$ \\
\hline Distribution & $\begin{array}{l}\text { Assumed is a transport by lorry of } 2,500 \mathrm{~km} \text { - representing the transport from the final assembly site (in Turkey) to Central } \\
\text { Western Europe, using average data for lorry transport from ecoinvent v2.01 }\end{array}$ \\
\hline Use & $\begin{array}{l}\text { Assumed is a use-during } 8 \text { years, } 4 \mathrm{~h} \text { on per day (more details: see text) - somewhere in Central Western Europe. } \\
\text { Therefore, the UCTE electricity mix, low voltage level, is used as default in this study here. Only for a sensitivity analysis, } \\
\text { the Swiss electricity mix, low voltage level, is used. }\end{array}$ \\
\hline \multirow[t]{2}{*}{$\begin{array}{l}\text { End-of-life } \\
\text { treatment }\end{array}$} & $\begin{array}{l}\text { An average transport distance (and a mix of transport mean) according to the Swiss recycling system is assumed for the transport } \\
\text { from the point of collection to the actual recycling plant. Then, the following fractions are distinguished for the disposal in the } \\
\text { framework of a state-of-the-art WEEE recycling system:-metal parts from housing: } 100 \% \text { recycling, including the secondary } \\
\text { production of aluminium and steel-plastic parts from housing: } 100 \% \text { incineration-plasma panel: } 100 \% \text { incineration-capacitors: } \\
100 \% \text { to specific capacitor disposal process, as established in the WEEE data of ecoinvent v2.01-electronics parts: } 100 \% \text { to a } \\
\text { precious metal recovery process, as established in the WEEE data of ecoinvent v2.01, including the secondary production of } \\
\text { gold, silver, palladium, nickel, copper and lead-cables: } 100 \% \text { to cable recycling process, as established in the WEEE data of } \\
\text { ecoinvent v2.01, including the secondary production of copper-packaging materials: EPS } 100 \% \text { to incineration/corrugated } \\
\text { board } 100 \% \text { recycling, including production of corrugated board paper out of secondary paper }\end{array}$ \\
\hline & $\begin{array}{l}\text { Credits are given in all cases of secondary production, i.e. a similar amount of primary production of the respective material } \\
\text { is given as credit. Furthermore, the electricity and heat produced in the incineration process results in a credit of the } \\
\text { respective amount of electricity (as Swiss electricity mix) or heat (as heat from light fuel oil boiler). }\end{array}$ \\
\hline
\end{tabular}

\subsubsection{Other television devices}

Concerning the two competing technologies, i.e. the LCD and the CRT technology, the LCI database ecoinvent (ecoinvent Centre 2007) contains only respective dataset for computer screens using these technologies. Thus, respective datasets for television devices of these two technologies were established here; for the CRT device, based on information from a recent dismantling trial within a Swiss WEEE recycling company and for the LCD device, based on information from a European Research project (Gaiker 2006), aiming to examine the possibilities of re-using LCD screens. CRT technology is limited in size for technical reasons, while LCD technology can be applied in a much broader range of sizes.

According to DCE (2007), combining LCD television sets of different sizes does not differ much, i.e. all components grow in about the same proportions; hence, the data from Gaiker (2006) can be used for either size of an LCD television device. According to a forecast from DisplaySearch (reported in DCE (2007)), the average LCD screen size in 2009 is in the order of $76 \mathrm{~cm}$ (taking into account computer screens as well as television devices) - compared with PDP devices with an average size of about $114 \mathrm{~cm}$. For this study, both competing technologies were modelled for a size of
32 in $(=81 \mathrm{~cm})$. Both devices were modelled in a manner similar to that used on the PDP devices described above.

\subsection{Impact assessment methods}

For the impact assessment, the two well-known Dutch LCIA methods were used: the Eco-Indicator '99 (Goedkoop and Spriensma, 2000) and the so-called Centrum voor Milieuwetenschappen (CML) methodology (Guinee et al. 2001). For the latter one, the various baseline impact categories were used, in order to get a comprehensive and detailed overview of the environmental impacts related to the examined television technology. In case of the EcoIndicator '99-used in this study in order to get a first indication of the overall environmental impact - the default way for grouping the three damage categories was used.

\section{Results}

3.1 The overall life cycle of a plasma television device

Examination of the environmental impacts along the complete life cycle of the plasma television device specified 
Table 4 Extract of important emission and resource factors out of the cumulative life cycle inventory results for the life cycle of a plasma television device

\begin{tabular}{|c|c|c|c|c|c|c|c|}
\hline & & \multirow[t]{2}{*}{ Total } & \multirow[t]{2}{*}{ Production } & \multirow[t]{2}{*}{ Distribution } & \multirow[t]{2}{*}{ Use } & \multicolumn{2}{|c|}{ End-of-life treatment } \\
\hline & & & & & & Efforts & Benefits \\
\hline \multicolumn{8}{|l|}{ Resource consumption } \\
\hline Aluminium, in ground & $\mathrm{kg}$ & $-3.93 \mathrm{E}-001$ & $9.77 \mathrm{E}+000$ & $1.62 \mathrm{E}-002$ & $2.56 \mathrm{E}-001$ & $7.57 \mathrm{E}-003$ & $-1.04 \mathrm{E}+001$ \\
\hline Calcite, in ground & $\mathrm{kg}$ & $1.09 \mathrm{E}+002$ & $8.39 \mathrm{E}+001$ & $4.56 \mathrm{E}-001$ & $2.75 \mathrm{E}+001$ & $3.83 \mathrm{E}+000$ & $-6.37 \mathrm{E}+000$ \\
\hline Coal, brown, in ground & $\mathrm{kg}$ & $8.72 \mathrm{E}+002$ & $1.13 \mathrm{E}+002$ & $4.86 \mathrm{E}-001$ & $7.74 \mathrm{E}+002$ & $1.39 \mathrm{E}+000$ & $-1.67 \mathrm{E}+001$ \\
\hline Coal, hard, in ground & $\mathrm{kg}$ & $4.96 \mathrm{E}+002$ & $8.75 \mathrm{E}+001$ & $7.50 \mathrm{E}-001$ & $4.30 \mathrm{E}+002$ & $1.68 \mathrm{E}+000$ & $-2.42 \mathrm{E}+001$ \\
\hline Copper, in ground & $\mathrm{kg}$ & $1.73 \mathrm{E}+000$ & $1.47 \mathrm{E}+000$ & $3.84 \mathrm{E}-003$ & $1.65 \mathrm{E}+000$ & $3.38 \mathrm{E}-002$ & $-1.43 \mathrm{E}+000$ \\
\hline Gas, natural, in ground & $\mathrm{Nm} 3$ & $2.46 \mathrm{E}+002$ & $5.68 \mathrm{E}+001$ & $6.56 \mathrm{E}-001$ & $1.95 \mathrm{E}+002$ & $3.36 \mathrm{E}+000$ & $-9.81 \mathrm{E}+000$ \\
\hline Gravel, in ground & $\mathrm{kg}$ & $2.13 \mathrm{E}+002$ & $1.56 \mathrm{E}+002$ & $1.40 \mathrm{E}+001$ & $5.93 \mathrm{E}+001$ & $7.25 \mathrm{E}+000$ & $-2.35 \mathrm{E}+001$ \\
\hline Iron, in ground & $\mathrm{kg}$ & $1.80 \mathrm{E}+001$ & $1.24 \mathrm{E}+001$ & $5.58 \mathrm{E}-001$ & $8.46 \mathrm{E}+000$ & $3.13 \mathrm{E}-001$ & $-3.75 \mathrm{E}+000$ \\
\hline Oil, crude, in ground & $\mathrm{kg}$ & $1.32 \mathrm{E}+002$ & $8.15 \mathrm{E}+001$ & $5.30 \mathrm{E}+000$ & $5.94 \mathrm{E}+001$ & $1.02 \mathrm{E}+000$ & $-1.52 \mathrm{E}+001$ \\
\hline $\begin{array}{l}\text { Energy, potential, converted } \\
\text { (in hydropower reservoir) }\end{array}$ & MJ & $2.21 \mathrm{E}+003$ & $5.89 \mathrm{E}+002$ & $5.26 \mathrm{E}+000$ & $1.94 \mathrm{E}+003$ & $1.29 \mathrm{E}+001$ & $-3.39 \mathrm{E}+002$ \\
\hline \multicolumn{8}{|l|}{ Emission to air } \\
\hline Carbon dioxide, fossil & $\mathrm{kg}$ & $2.60 \mathrm{E}+003$ & $6.37 \mathrm{E}+002$ & $1.78 \mathrm{E}+001$ & $2.04 \mathrm{E}+003$ & $3.31 \mathrm{E}+001$ & $-1.25 \mathrm{E}+002$ \\
\hline Sulphur dioxide & $\mathrm{kg}$ & $6.31 \mathrm{E}-001$ & $2.40 \mathrm{E}+000$ & $2.45 \mathrm{E}-002$ & $7.10 \mathrm{E}+000$ & $4.37 \mathrm{E}-002$ & $-8.93 \mathrm{E}+000$ \\
\hline Nitrogen oxides & $\mathrm{kg}$ & $5.29 \mathrm{E}+000$ & $1.95 \mathrm{E}+000$ & $9.33 \mathrm{E}-002$ & $3.59 \mathrm{E}+000$ & $3.99 \mathrm{E}-002$ & $-3.84 \mathrm{E}-001$ \\
\hline Methane, fossil & $\mathrm{kg}$ & $4.49 \mathrm{E}+000$ & $1.12 \mathrm{E}+000$ & $2.38 \mathrm{E}-002$ & $3.54 \mathrm{E}+000$ & $3.03 \mathrm{E}-002$ & $-2.21 \mathrm{E}-001$ \\
\hline $\begin{array}{l}\text { PAH, polycyclic aromatic } \\
\text { hydrocarbons }\end{array}$ & $\mathrm{kg}$ & $1.05 \mathrm{E}-004$ & $7.81 \mathrm{E}-004$ & $2.16 \mathrm{E}-006$ & $1.23 \mathrm{E}-004$ & $2.77 \mathrm{E}-006$ & $-8.03 \mathrm{E}-004$ \\
\hline \multicolumn{8}{|l|}{ Emission to water } \\
\hline COD, chemical oxygen demand & $\mathrm{kg}$ & $9.91 \mathrm{E}+000$ & $9.19 \mathrm{E}+000$ & $5.36 \mathrm{E}-002$ & $9.38 \mathrm{E}-001$ & $1.77 \mathrm{E}-001$ & $-4.55 \mathrm{E}-001$ \\
\hline Chloride & $\mathrm{kg}$ & $1.65 \mathrm{E}+001$ & $8.95 \mathrm{E}+000$ & $2.37 \mathrm{E}-001$ & $8.05 \mathrm{E}+000$ & $1.66 \mathrm{E}-001$ & $-8.99 \mathrm{E}-001$ \\
\hline Sulphate & $\mathrm{kg}$ & $1.62 \mathrm{E}+001$ & $4.97 \mathrm{E}+000$ & $1.25 \mathrm{E}-002$ & $1.19 \mathrm{E}+001$ & $6.84 \mathrm{E}-002$ & $-7.22 \mathrm{E}-001$ \\
\hline Ammonium, ion & $\mathrm{kg}$ & $1.43 \mathrm{E}-002$ & $1.01 \mathrm{E}-002$ & $4.17 \mathrm{E}-005$ & $4.62 \mathrm{E}-003$ & $3.24 \mathrm{E}-005$ & $-4.63 \mathrm{E}-004$ \\
\hline Nickel, ion & $\mathrm{kg}$ & $1.15 \mathrm{E}-002$ & $9.23 \mathrm{E}-003$ & $8.74 \mathrm{E}-005$ & $8.26 \mathrm{E}-003$ & $5.95 \mathrm{E}-003$ & $-1.20 \mathrm{E}-002$ \\
\hline Cobalt, ion & $\mathrm{kg}$ & $2.84 \mathrm{E}-003$ & $1.85 \mathrm{E}-003$ & $1.35 \mathrm{E}-005$ & $3.28 \mathrm{E}-003$ & 7.04E-004 & $-3.01 \mathrm{E}-003$ \\
\hline Vanadium, ion & $\mathrm{kg}$ & $1.05 \mathrm{E}-002$ & $8.90 \mathrm{E}-003$ & $3.31 \mathrm{E}-005$ & $6.67 \mathrm{E}-003$ & $2.62 \mathrm{E}-004$ & $-5.39 \mathrm{E}-003$ \\
\hline
\end{tabular}

here - partly documented in Table 4-yielded the environmental impacts shown in Fig. 2. These results are shown on a relative scale, taking the impact of the use phase (calculated with the UCTE electricity mix) as $100 \%$. As can be seen from Fig. 2, all CML factors - and also the total value of the Eco-Indicator '99-show a similar picture, i.e. the distribution is of no importance, the EoL phase leads to a more or less important environmental benefit, while the remaining two phases (production, use) show rather important environmental impacts. In the details, however, there are rather large differences among the various impact factors - i.e. production comprises $15 \%$ (terrestrial ecotoxicity) to more than $130 \%$ (human toxicity) as compared with the use phase. And the environmental benefits due to the EoL phase varies between about 5\% (resource depletion) and more than 100\% (acidification, photochemical oxidation) of benefits compared with the respective impact of the use phase. A more detailed analysis and the origins of these values can be found in Chapter 3.2 describing the various life cycle phases.
From the four distinguished life cycle stages, the importance of the use phase depends on the actual production mix used for the electricity consumed. As shown in Fig. 3 for the Eco-Indicator '99 result, a change to a more renewable electricity mix such as, e.g. that used in Switzerland, results in an impact for the use phase that is about three times lower, i.e. only about half compared with the production phase. Using the various impact categories from the CML methodology yields a reduction for the use phase between $15 \%$ (terrestrial ecotoxicity) and $85 \%$ (acidification), i.e. the use phase being three times higher than the use phase for the factor of acidification.

3.2 Details of the various life cycle phases

\subsubsection{Production}

For the production phase, a comparison between the various parts and production steps of such a PDP television device is shown in Fig. 4. It can be clearly seen that the 
Fig. 2 The complete life cycle of a plasma television device (relative to the impact of the use phase-calculated with the UCTE electricity mix). Shown are the following impact factors from the CML method: $A R D$ abiotic resource depletion, GWP global warming potential, $O D P$ stratospheric ozone depletion potential, $P C O P$ photochemical oxidation potential, $A P$ acidification potential, $E P$ eutrophication potential, HTP human toxicity potential, FAETP freshwater aquatic ecotoxicity potential, MAETP marine aquatic ecotoxicity potential, TETP terrestrial ecotoxicity potential as well as the total of the Eco-Indicator '99 method (EI'99)

Production

. D Distribution

Use

End-of-Life treatment

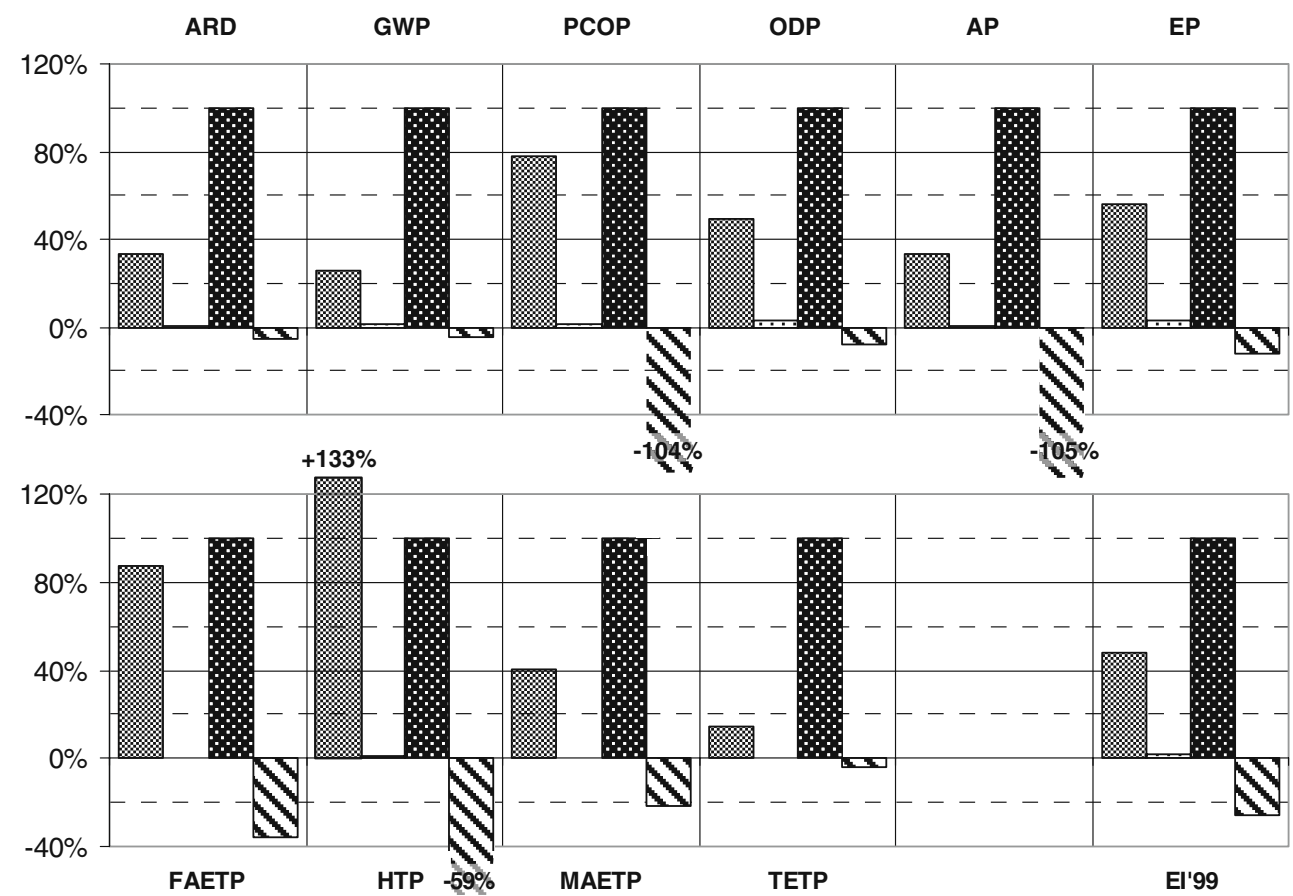

main impact is due to the PWB-within the total of the Eco-Indicator ' 99 the PWB are responsible for almost $75 \%$ of the impact of the production phase; the next highest impact is due to the housing that is responsible for about $15 \%$, followed by the various assembly activities $(5 \%)$ and the actual PDP unit (3\%). Within the factors of the CML methodology examined, the two most important parts are again always the various PWB, having an impact ranging from $44 \%$ (human toxicity) up to $86 \%$ (photochemical oxidation) and the housing with an impact between $7 \%$ (photochemical oxidation) and 53\% (human toxicity). In case of $\mathrm{PWB}$, the high impacts in case of photochemical oxidation are due to the sulphur dioxide $\left(\mathrm{SO}_{2}\right)$ emissions to air in the production of palladium as well as the air emissions of ethyl acetate and methyl ethyl ketone in the production process of the various electronic components (i.e. capacitors, inductors, etc.) For acidification and eutrophication - also both largely dominated by the $\mathrm{PWB}$ - this is due to the $\mathrm{SO}_{2}$ emissions to air in the production of palladium (acidification) or due to the nitrogen oxides to air and the COD emissions from the disposal processes in the wafer production (eutrophication). The high impact of the housing in case of human toxicity is due to the aluminium parts of the housing and there actually due to polycyclic aromatic hydrocarbons (PAH) emissions to air, which are responsible for more than $90 \%$ of this impact. Also, in case of the aquatic ecotoxicity factors [freshwater aquatic ecotoxicity potential (FAETP); marine aquatic ecotoxicity potential (MAETP)], these aluminium parts are responsible for more than $80 \%$ of the impact coming from the housing. In both cases, vanadium ion emissions to water due to the treatment of waste from the bauxite digestion are responsible for $76 \%$ (MAETP) to $94 \%$ (FAETP) of this impact. Only in case of resource depletion does the actual PDP unit have an impact of more than $20 \%$ of the total impact due to the xenon gas in the filling, responsible for about $90 \%$ of this impact; in all other aspects, the PDP unit is of minor interest. The impact due to the assembly activities is of minor interest and varies between only about 1\% (human toxicity) and about $8 \%$ (climate change).

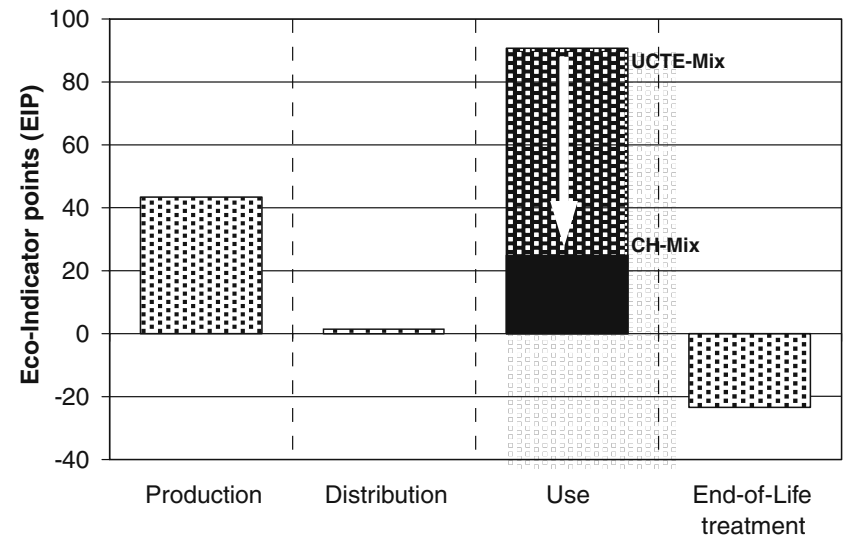

Fig. 3 Influence of a change in the electricity mix during the use phase on the complete life cycle of a plasma television device, expressed as the total of the Eco-Indicator ' 99 


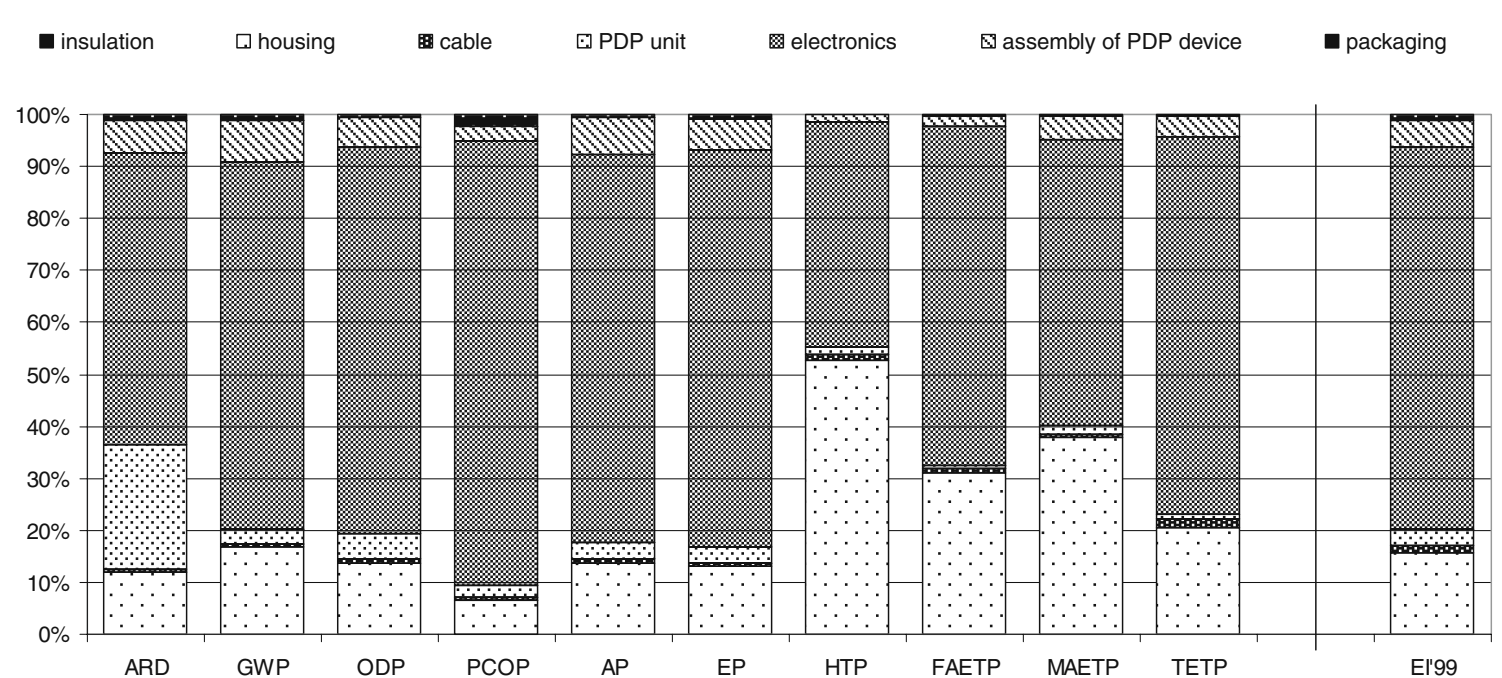

Fig. 4 The production phase of a plasma television device, expressed with CML and Eco-Indicator '99 method (for abbreviations of shown impact factors, see legend of Fig. 2)

\subsubsection{Use}

The environmental impact of the use phase is only due to the use of electricity (here, the UCTE electricity mix), i.e. the contributions to the impact due to the use phase are equal to those of the respective electricity mix. This impact can be changed considerably by changing the electricity mix, as shown in Fig. 3 for the case of the Swiss electricity mix.

\subsubsection{End-of-life treatment}

The EoL phase finally, as shown in Fig. 2, does not cause an impact but can have an environmental benefit if state-ofthe-art recycling technologies are assumed. In Fig. 5, the various impacts or benefits from the EoL phase are shown in detail. It can be seen that only three processes contribute to the benefits - the recycling of metal parts (of the housing), the recycling of PWB and the energy recovery from, e.g. incineration processes). However, the latter one is of minor importance, as its value never contributes more than $10 \%$ to the overall benefits - all other benefits are due to the burdens avoided during the production of primary metals, either due to the recycling of the metallic parts of the housing or due to the recovery of the precious metal content in the PWB. On the other hand, i.e. the impacts due to EoL processes, the only process with a relevant impact is the incineration of the plastic parts. However, these impacts are never higher than $35 \%$ compared with the benefits.

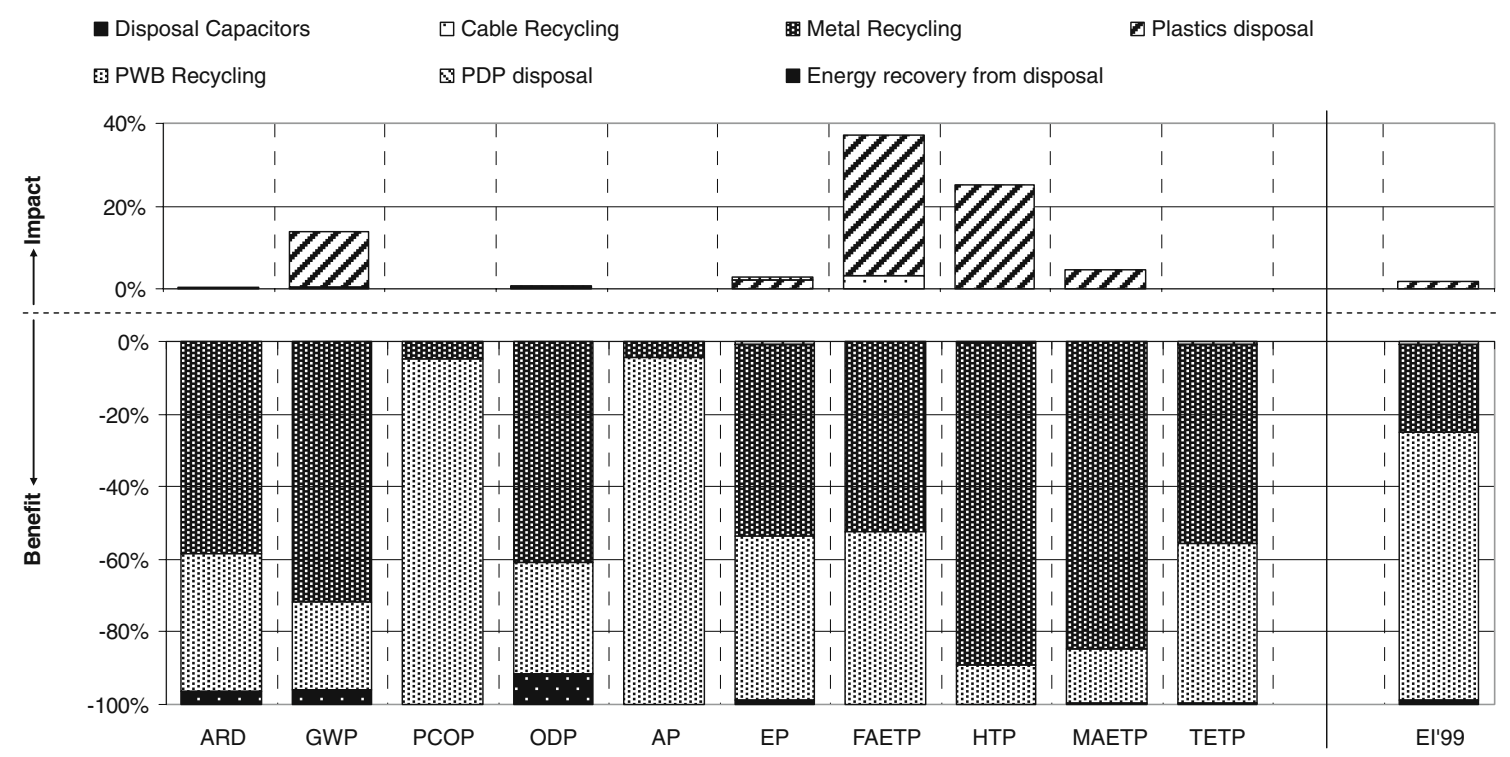

Fig. 5 The end-of-life phase of a plasma television device - environmental benefits due to a state-of-the-art recycling, expressed with CML and Eco-Indicator ' 99 method (for abbreviations of shown impact factors, see legend of Fig. 2) 
Going back to Fig. 2, we see that the impact categories photochemical oxidation, acidification and human toxicity show a clearly higher benefit - ranging from 60 to $105 \%$ in relation to the impact of the use phase-from the EoL processes than all other impact categories. These high values are due to the avoided primary production of aluminium (and its PAH emissions to air) in case of human toxicity or due to the avoided primary production of palladium (and its high $\mathrm{SO}_{2}$ emissions to air) in case of photochemical oxidation and acidification.

\subsection{Comparison with competing technologies (LCD, CRT)}

Due to the different sizes of the devices examined, reflecting the limits and market conditions of the various technologies for 2009, a comparison based on the numbers of these devices in use would not really be accurate. Therefore, a relative comparison was established instead for a more adequate comparison of the three technologies, as according to DCE (2007), all three technologies have an electricity consumption in the use phase that is directly proportional to the surface of the screen. Hence, a comparison per square metre of surface can be established. The results are shown in Fig. 6.
As can be seen from Fig. 6, LCD technology almost always shows the highest environmental impact, or it shows an impact close to the highest impact. PDP technology, on the other hand, shows the lowest impact in the case of stratospheric ozone depletion, photochemical oxidation, acidification, eutrophication, human toxicity and freshwater ecotoxicity; for resource depletion, global warming and marine ecotoxicity, the CRT and the PDP technology have a rather similar impact. While the differences in the use phase are rather small-the production of the three different television devices shows rather large differences. Especially, the impact categories of human toxicity and freshwater ecotoxicity show an impact for the production of the LCD or CRT devices two and more times higher than PDP television. In the case of the CRT screen, this high impact is due to the nickel, cobalt and vanadium emissions to water (in the case of freshwater ecotoxicity) or due to chrome (VI), arsenic and PAH emissions to air (for human toxicity), originating from the PWB and the chrome steel used in a CRT device - in the LCD case, the LCD module itself is responsible for the main part of this impact due to the same types of emissions as in the CRT case, originating mainly from the assembly process of the LCA module itself, as well as from the used amount of chrome steel and the PWB
Fig. 6 Comparison of PDP, LCD and CRT technology.

Shown are relative values per square inch (i.e. per $6.45 \mathrm{~cm}^{2}$ ), with the value of the LCD screen being set as $100 \%$, expressed with CML and EcoIndicator ' 99 method (for abbreviations of shown impact factors, see legend of Fig. 2). In the right lower corner, absolute values for the Eco-Indicator ' 99 method are shown-again with the value of the LCD screen being set as $100 \%$ $\square$ Production
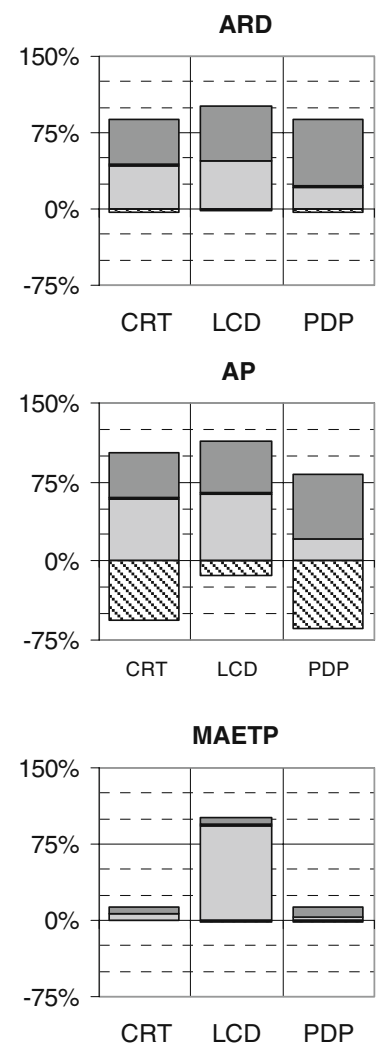

Distribution

relative Comparison per Square-Inch

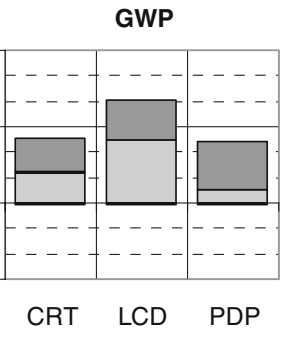

EP

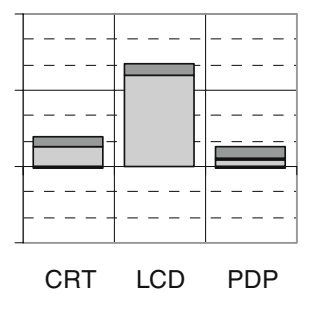

TETP

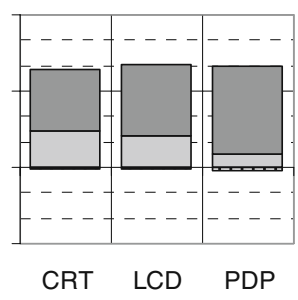

ODP
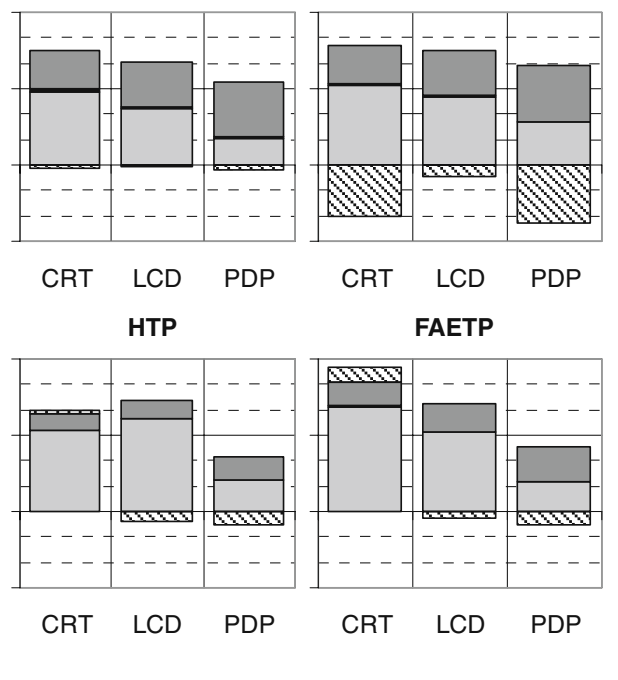

El'99

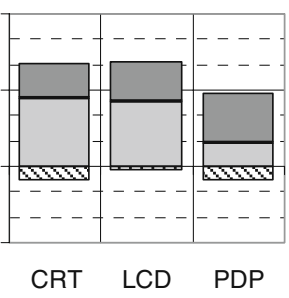


used. In case of global warming, eutrophication and marine ecotoxicity, the LCD module shows an impact in the production phase several times higher than the two other technologies. A more detailed analysis shows that the high impact in global warming is due to the emissions of $\mathrm{CO}_{2}$ and $\mathrm{SF}_{6}$ to air in the assembly stage, in the case of eutrophication again the assembly stage, this time with its emissions of HF to air or vanadium and nickel to water, is responsible for this high impact and the marine ecotoxicity is dominated by nitrate, ammonium and COD values to water, resulting from the waste water treatment in the assembly stage. On a more general level, however, all three technologies nevertheless show a similar picture-production and use having high impacts, distribution being irrelevant and EoL resulting mostly in an ecological benefit.

\subsection{Comparison with other studies}

As mentioned in Section 1, there is only one known study dealing with the environmental impacts of these three television technologies, Aoe (2003), reporting however only on global warming and resource consumption data. According to the paper, the shown data represent 32-inch television devices that were used for 8 years; thus the data can be rather easily compared with the data from this study, at least for the factor of global warming (while the factors for resource consumption in the CML methodology and in Aoe (2003) are not calculated in the same way). According to the data from ecoinvent, the global warming of the Japanese electricity mix has a difference below $2 \%$ in comparison with the one from the UCTE mix. Thus, the calculations from this study should be comparable to the numbers in Aoe (2003). On the basis of a square metre of surface (again in order to correct the differences in sizes), the numbers from Aoe (2003) show for the PDP television a rather good accordance with differences of less than $5 \%$ (for the total life cycle) or around $8.5 \%$ (only the use phase). However, for the two other technologies - the differences are much higher, although both studies look for them on the same size of devices. While in case of CRT technology, taking the total life cycle leads to a difference of more than $50 \%$, LCD technology shows a difference of almost $140 \%$. Looking at the use phase only shows a difference around $6 \%$ (CRT) to $35 \%$ (LCD). A possible explanation for these huge differences especially concerning the production of the devices can be found in a more detailed modelling within this study, based on the new, detailed electronics datasets from ecoinvent. For the use phase, the number used for the power consumption of each type of devices is very important, but, at the same time, this number can vary very much, as shown in Table 1 for PDP technology. While for PDP technology, both studies use rather similar values for the power consumption of the device, Aoe (2003) seem to use very different numbers for the electricity consumption in the use phase for the two competing technologies, especially for the LCD television device; however, no such information on that is given in the mentioned paper.

\section{Conclusions and outlook}

This study emphasises that it is advisable to use electronic devices as long as possible due to the high impact of the production phase, especially when the technical lifetime is far beyond the current use of such devices, as in case of the two flat screen technologies (i.e. LCD and PDP) examined here. From the results shown for the production phase, it can be deduced that the impact of electronic components is much higher than the impact of other, even metallic materials. But, as is also shown here, one part of this high environmental impact in the electronic components can be recovered by an up-to-date recycling system with a maximum recovery of metals, especially precious ones.

Another important life stage is the use phase, i.e. that life stage that depends on the production mix of the electricity consumed. As shown here, a switch from a predominantly non-renewable electricity mix (as the UCTE mix) to a much more renewable mix (here the Swiss electricity mix is used as an example) can reduce the overall impact of the use phase considerably. But, independently of the actual electricity mix, it can be concluded that an electronic component such as a television should only be turned on when it is really used-otherwise the device should be turned off completely including its stand-by.

In the comparison of the three screen technologies, the PDP devices show the least impact on the environment in relation to their screen surface. In absolute numbers, it is the power consumption in the use phase, in particular, that is the highest; however, the PDP screen is usually also bigger than a CRT or an LCD screen. In addition, the comparison of the three technologies shows that the production of the LCD screen has a clearly higher impact on the environment than the PDP. However, it has to be taken into account that, for this study, average devices of each of the technologies were taken into account, especially concerning the electricity consumption in the use phase. Here, further studies should take over and investigate the variability in the electricity consumption in the use phase depending on the technology used-and the respective consequences from this on the relative comparison of the three screen technologies established here (related to the screen surface). In addition, new flat technologies are about to enter the market-hence, further studies have to widen the field of the technologies taken into account in order to 
allow our society to use its communication medium no. 1 in the most sustainable way possible.

Acknowledgement We gratefully acknowledge Empa and Heig-VD for the funding of the here presented activities. In addition, we would acknowledge Prof. Lorenz Hilty and the anonymous reviewers for their valuable comments, allowing us to further improve this publication.

\section{References}

Abramson A (1987) The history of television, 1880 to 1941. McFarland and Company, Inc., Publishers, Jefferson, NC

Aoe, T. (2003). Case study for calculation of factor X (Eco-Efficiency) - comparing CRT TV, PDP TV and LCD TV. EcoDesign Conference, Tokyo (Japan)

Baudin, I. (2006). Life cycle analysis of a plasma display [Analyse du cycle de vie d,un écran plasma] comem+. Yverdon (Switzerland), Haute Ecole d, Ingénierie et de Gestion du Canton de Vaud.

DCE (2007). Television energy rating labels: the case, and proposal, for MEPS and labelling televisions-discussion paper. Leura (Australia), Digital CEnergy (DCE).

ecoinvent Centre (2007). ecoinvent data v2.0. Dübendorf, CH, Swiss Centre for Life Cycle Inventories.

Eden JG (2006) Information display early in the 21st century: overview of selected emissive display technologies. Proc IEEE 94(3):567-574

Eugster M, Hischier R, Huabo D (2007) Key environmental impacts of the Chinese EEE-industry - a life cycle assessment study. Empa and Tsinghua University, St Gallen

Gaiker (2006). Liquid crystal display re-use and recycling "Re-LCD". Project result presentation. Vienna (Austria), ReLCD Project.

Goedkoop, M. and Spriensma, R. (2000). Eco-indicator 99. A damage orientated method for life cycle impact assessment. Methodology Report. Amersfoort, PRé Consultants B. V.: 132.

Guinee, J., Gorrée, M., Heijungs, R., Huppes, G., Kleijn, R., de Koning, A., van Oers, L., Wegener Sleeswijk, A., Suh, S., Udo de Haes, H.A., de Bruijn, H., van Duin, R. and Huijbregts, M.A. J. (2001). Life cycle assessment - an operational guide to the ISO standards, Centre of Environmental Sciences (CML), Leiden University.

Hilty L (2005) Electronic waste - an emerging risk? Environ Impact Asses Rev 25:431-435

Hilty, L. (2008). Information technology and sustainability. Norderstedt (Germany), BoD (Books on Demand).

Hilty, L., Hischier, R., Ruddy, T.F. and Som, C. (2008). Informatics and the Life Cycle of Products. iEMSs 2008: International Congress on Environmental Modelling and Software, Barcelona (Spain), International Environmental Modelling and Software Society (iEMSs).

Hischier R, Wäger P, Gauglhofer J (2005) Does WEEE recycling make sense from an environmental perspective? The environmental impacts of the Swiss take-back and recycling systems for waste electrical and electronic equipment (WEEE). Environ Impact Asses Rev 25:525-539

Huabo D, Eugster M, Hischier R, Streicher-Porte M, Jinhui L (2009) Life cycle assessment study of a Chinese desktop personal computer. Sci Total Environ 407(5):1755-1764

Inguchi, Y., Deguchi, Y., Masaki, T. and Mikami, Y. (2005). Board for plasma display with barrier ribs, plasma display and production process therefor. Tokyo (Japan), United States Patent (Patent No. US 6,870,315 B2) from Toray Industries Inc.

IPTS (2003). Environmental, technical and market analysis concerning the eco-design of television devices. Sevilla (Spain), European Commission, Joint Research Centre (JRC)-Institute for Prospective Technological Studies (IPTS).

Lee, Y.K. (2006). Composition of plasma display panel. Seoul (SouthKorea), United States Patent (Patent No. US 7,009,330 B2) from LG Electronics Inc.

Matsushita (2006) Annual report 2006. Matsushita Electric Industrial Co., Ltd, Osaka

Nishitani, M., Morita, Y., Kitagawa, M. and Terauchi, M. (2006). Plasma display panel and manufacturing method therefore. Osaka (Japan), United States Patent (Patent No. US 7,102,287 B2) from Matsushita Electric Industrial Co., Ltd.

Scharnhorst, W. (2005). Life-Cycle assessment of mobile telephone networks, with focus on the environmental relevance of the endof-life phase. EPFL-ENAC-ISTE. Lausanne, Swiss Federal Institute of Technology.

Scharnhorst W, Hilty L, Jolliet O (2006) Life cycle assessment of second generation $(2 \mathrm{~g})$ and third generation $(3 \mathrm{~g})$ mobile phone networks. Environ Int 32:656-675

Snijkers, R. and Klein, M. (2002). Plasma display. Eindhoven (The Netherlands), United States Patent (Patent No. US 6,476,554 B1) from Koninklijke Philips Electronics N.V.

Socolof ML, Overly JG, Geibig JR (2005) Environmental life-cycle impacts of CRT and LCD desktop computer displays. J Clean Prod 13:1281-1294

Song J-Y, Choi S-Y (2006) Fabrication and characterization of Pb-free transparent dielectric layer for plasma display panel. Displays $27: 112-116$

Stobbe, L. (2007a). EuP preparatory studies "Televisions" (Lot 5) Final Report on Task 2 "Economic and Market Analysis". Berlin (Germany), Öko-Institute and Fraunhofer Institute for Reliability and Microintegration (IZM).

Stobbe, L. (2007b). EuP preparatory studies "Televisions" (Lot 5) -Final Report on Task 3 "Consumer Behaviour and Local Infrastructure". Berlin (Germany), Deutsche Umwelthilfe and Fraunhofer Institute for Reliability and Microintegration (IZM).

Stobbe, L. (2007c). EuP preparatory studies "Televisions" (Lot 5) Final Report on Task 4 "Technical Analysis". Berlin (Germany), Fraunhofer Institute for Reliability and Microintegration (IZM).

von Geibler, J., Ritthoff, M. and Kuhndt, M. (2003). The environmental impacts of mobile computing. A case study with HP. Digital Europe: e-business and sustainable development. Wuppertal, Wuppertal Institute: 43.

Widmer R, Oswald-Krapf H, Sinha-Khetriwal D, Schnellmann M, Boni H (2005) Global perspectives on e-waste. Environ Impact Asses Rev 25(5):436-458 